The era of railroad building ended long ago. It was in that era that Iowa life took on the forms that will endure through the ages. Nor was the era so very far in the past. The writer well remembers being present at the forks of the Raccoon river, 20 miles west of Des Moines, when the first "Iron horse," as we called the early locomotives, proceeded past the Des Moines river valley, and gave the signal for a barbecue and rejoicing. The whistle gave forth a sound as strange to the ox-team drivers as the modern Diesel's moan seems to the drivers at the auto wheels.

Times do change, even in one generation. All honor to "Hub" and his friends.

\title{
Kasson and Hoxie Leadership
}

Supplementing his comment upon Dodge, Palmer, Kasson and Hoxie, in a letter to Edgar R. Harlan, referred to by Ora Williams, on page 328, Frank M. Mills wrote another letter to Mr. Harlan in which he touched upon the activities of the same parties. It was dated January 27,1921 , evidently in reply to a query from Harlan, and included the following:

I can add but little in regard to Mr. Kasson which is not covered by his autobiography published in the Annals, except what I wrote you last October. He was a good straight Republican, a first-class organizer. He and Hub Hoxie gave the trend to Iowa politics which it retained until of late years ...

Mr. Kasson was courtly and would be conspicuous in the highest circles. It is understood that he was a great favorite in the courts abroad where he represented the United States. Except during the sessions of the Iowa legislature in which he represented Polk county for the purpose of securing appropriations for the capitol building, he was either at Washington or abroad in diplomatic service...

I a mfree to say that I think him the greatest character that Iowa has produced ... I am glad that history of his life and services is to be published. 
Copyright of Annals of Iowa is the property of State of Iowa, by \& through the State Historical Society of Iowa and its content may not be copied or emailed to multiple sites or posted to a listserv without the copyright holder's express written permission. However, users may print, download, or email articles for individual use. 